\title{
Distribution and degranulation of airway mast cells in normal and asthmatic subjects
}

\author{
N.G. Carroll*, S. Mutavdzic" ${ }^{\#}$ A.L. James ${ }^{\#}$
}

Distribution and degranulation of airway mast cells in normal and asthmatic subjects. N.G. Carroll, S. Mutavdzic, A.L. James. (C) ERS Journals Ltd 2002.

ABSTRACT: It was hypothesized that the distribution and activation of mast cells across the airway wall may reflect their function in asthma.

The density of mast cells (intact and degranulated) within airway compartments in cartilaginous and membranous airways, obtained from autopsies on patients with fatal asthma, nonfatal asthma, and nonasthmatic control cases have been examined.

In cartilaginous airways, the mean $\pm \mathrm{SE}$ density of mast cells in control cases was $27 \pm 9$ cells $\cdot \mathrm{mm}^{-2}$. It was similar in nonfatal asthma $\left(24 \pm 2\right.$ cells $\left.\cdot \mathrm{mm}^{-2}\right)$ but reduced $(p<0.05)$ in fatal asthma cases $\left(16 \pm 2\right.$ cells $\left.\cdot \mathrm{mm}^{-2}\right)$. In membranous airways, the density of mast cells in control cases was $155 \pm 21$ cells $\cdot \mathbf{m m}^{-2}$ and was higher $(p<0.05)$ in cases of nonfatal $\left(270 \pm 51\right.$ cells $\left.\cdot \mathrm{mm}^{-2}\right)$ and fatal asthma $\left(219 \pm 26\right.$ cells $\left.\cdot \mathrm{mm}^{-2}\right)$. Mast-cell density was greatest on the smooth muscle and mucous glands in cartilaginous airways and on the smooth muscle and outer airway wall in membranous airways. The percentage of degranulated mast cells was higher $(p<0.05)$ in cases of asthma, related to disease severity, and was higher in cartilaginous than membranous airways. Degranulation was greatest on the smooth muscle in fatal asthma cases.

Mast-cell distribution and degranulation varies between cartilaginous and membranous airways and across the airway wall. Degranulation of mast cells is related to asthma severity. The increased degranulation in proximal airways may reflect stimulation via the inhaled route.

Eur Respir J 2002; 19: 879-885.
*Faculty of Regional Professional Studies, Edith Cowen University, Bunbury and ${ }^{\#}$ Dept of Pulmonary Physiology, Sir Charles Gairdner Hospital, Nedlands, Western Australia.

Correspondence: N. Carroll, Faculty of Regional Professional Studies, Edith Cowen University, Robertson Drive, Bunbury, WA 6230, Australia.

Fax: 61897807814

E-mail: n.carroll@ecu.edu.au

Keywords: Asthma, mast cells, pathology

Received: August 232001

Accepted after revision November 27 2001

This study was supported by the Asthma Foundation of Western Australia, National Health and Medical Research Council, Australia.
Asthma is a disease characterized by airway inflammation [1] and remodelling [2]. It has been suggested, but not proven, that inflammation results in remodelling.

The extent to which inflammatory cells interact with airway wall structures (which are subject to remodelling) depends on the distribution of inflammatory cells across the airway wall. Two studies $[3,4]$ have shown an increase in the numbers of mast cells found on the smooth muscle layer in isolated sensitized human bronchi compared with nonsensitized airways. Mast cells are present in varying numbers in patients with asthma [5-10]. Their role in inflammatory reactions relates to their ability to store and release, or synthesize de novo, mediators of inflammation [11]. The multiple actions of mast-cell derived mediators suggest that mast cells might interact with airway structures.

When mast cells are activated they become partly or completely degranulated [5]. However, the extent to which this occurs in asthma and its relationship to disease severity has not been quantified. A further rationale for studying the distribution of inflammatory cells across the airway wall in large and small airways is to determine the degree to which assessing inflammation by sampling the proximal bronchial tree is representative of airway inflammation in the distal bronchial tree. Therefore, the aim of this study was to examine the distribution of mast cells and their degree of degranulation within the airway wall of the large and small airways of subjects without respiratory disease and compare them with patients with asthma.

\section{Methods}

\section{Cases}

The left or right lung was obtained at Coroner's autopsy if the cause of death was asthma or if death occurred suddenly, without chest trauma or illness (other than asthma). Medical histories were obtained retrospectively from family members, usual medical practitioner and hospital files. As described previously [2], cases were categorized as follows. 1) Control: no history of asthma, wheeze, use of asthma medications or other lung disease; 2) nonfatal asthma: sudden nonrespiratory death but with a definite history of asthma; and 3) fatal asthma: death due only to asthma. Cases were excluded from the study if details of medical history could not be obtained. Ethical approval for the study was obtained from the Sir Charles Gairdner Hospital's Ethics Committee.

\section{Histological preparation}

Lungs were fixed in formalin and transverse blocks of all large conducting airways down to the 
subsegmental level were cut, resulting in 12-18 large cartilaginous airways per case, from which five were randomly selected for this study. Six parenchymal sections $(3 \times 2 \times 1 \mathrm{~cm})$ were taken at random from the midsaggital slice of the lung. Tissue sections were cut $(5 \mu \mathrm{m})$ and stained using the immunoperoxidase technique with the antimast cell tryptase monoclonal antibody AA1 (Dako Patts, Copenhagen, Denmark).

\section{Airway dimensions}

Airway dimensions (inner and outer airway wall thickness and areas of smooth muscle, submucosal mucous glands and cartilage) were measured as previously described [2]. The basement membrane perimeter $(\mathrm{Pbm})$ was directly traced using a camera lucida and a digitizing tablet.

\section{Cell counts}

Mast cells with a visible nucleus were counted and expressed as total number in each of the previously discussed compartments and cells $\cdot \mathrm{mm}^{-2}$ of each compartment area (cell density). The percentage of total airway mast-cell count in each airway compartment was calculated.

\section{Mast-cell degranulation}

At high power $(\times 400)$, positively-stained nucleated mast cells were classified as intact if they were dense, compact, had unbroken cytoplasmic boundaries and did not have any surrounding positively stained granules (fig. 1). All other nucleated tryptase positive cells were classified as degranulated (fig. 2). Degranulated cells were expressed as a per cent of the total number of nucleated AA1-positive cells for the whole airway section and for each compartment.

Intraobserver error was calculated for airway

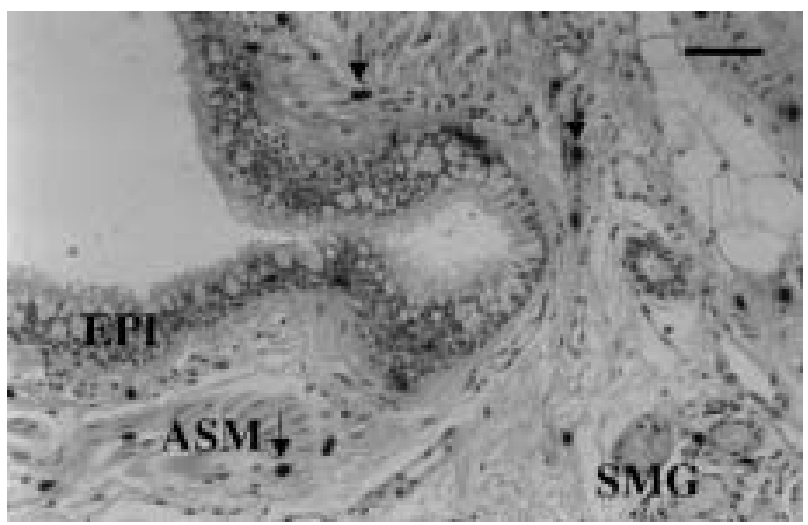

Fig. 1.-A transverse section of a large cartilaginous airway showing mast cell tryptase positive cells (arrows) present in the airway wall including epithelium (EPI), airway smooth muscle (ASM) and submucosal mucous glands (SMG). Most mast cells demonstrate dense homogeneous staining with little extracellular tryptase positivity and were classified as intact mast cells. Scale bar $=100 \mu \mathrm{m}$

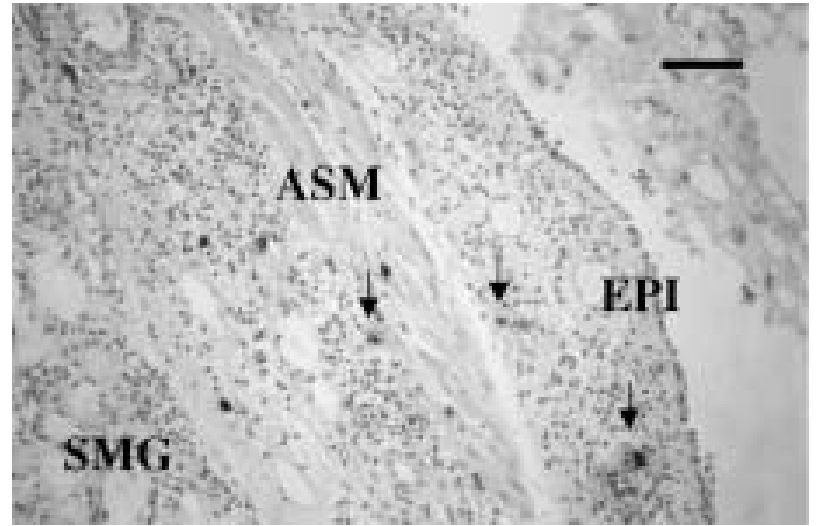

Fig. 2.-A transverse section of a large cartilaginous airway showing mast cell tryptase positive cells (arrows) present in the airway wall showing damaged epithelium (EPI), airway smooth muscle (ASM) and submucosal mucous glands (SMG). In this section, most mast cells demonstrate a lack of dense homogeneous staining and an abundance of extracellular tryptase positivity (arrows) and were classified as degranulated mast cells. Scale bar $=100 \mu \mathrm{m}$.

dimensions, cell counts and degranulation index, as previously described [2]. All measurements were made by one observer (N.G. Carroll), blinded to case histories.

\section{Data analysis}

The mean of each case group, calculated from the means of each case, was used for analysis. Bartlett's test for homogeneity of variances was performed. Where data was normally distributed, differences between groups were tested using parametric analysis (one way analysis of variance (ANOVA)) and where data was not normally distributed, nonparametric tests (Kruskal-Wallis nonparametric ANOVA) were used followed by Dunn's multiple comparison test. A probability value of $<5 \%$ was considered significant.

\section{Results}

\section{Subject characteristics}

The cases of fatal asthma were generally severe, as defined by treatment requirements and symptoms, and had measurable airflow obstruction (table 1). The cases of nonfatal asthma were generally mild with infrequent symptoms.

\section{Total airway wall}

There were no significant differences in the size $(\mathrm{Pbm})$ of the cartilaginous or membranous airways examined in each of the three case groups (table 2).

In cartilaginous airways, the absolute number and density of mast cells on transverse section were higher $(p<0.05)$ in cases of nonfatal asthma and control cases compared with cases of fatal asthma. In membranous airways they were higher $(p<0.05)$ in 


\begin{tabular}{|c|c|c|c|}
\hline & Control & Nonfatal & Fatal \\
\hline Subjects $n$ & 8 & 8 & 8 \\
\hline Male/female & $5 / 3$ & $4 / 4$ & $4 / 4$ \\
\hline Age yrs mean $\pm \mathrm{sD}$ & $38 \pm 14$ & $39 \pm 17$ & $31 \pm 16$ \\
\hline \multicolumn{4}{|l|}{ Treatment $\mathrm{n}$} \\
\hline Bronchodilator & 0 & 8 & 8 \\
\hline Inhaled corticosteroid & 0 & 2 & 8 \\
\hline Oral corticosteroid & 0 & 0 & 6 \\
\hline Asthma symptoms & Nil & $\begin{array}{c}\text { Weekly } 3 \text { of } 8 \\
\text { Occasional } 5 \text { of } 8\end{array}$ & $\begin{array}{c}\text { Daily } 7 \text { of } 8 \\
\text { Occasional } 1 \text { of } 8\end{array}$ \\
\hline Time off work or hospitalization due to asthma $n$ & 0 & 1 & 7 \\
\hline Duration of asthma yrs mean (range) & Nil & $14(2-36)$ & $18(2-40)$ \\
\hline Lung function FEV $1 \%$ pred mean (range) & NA & NA & $68(35-90)$ \\
\hline
\end{tabular}

FEV1: forced expiratory volume in one second; NA: not available.

Table 2. - Mast cell counts across the total airway wall in cartilaginous and membranous airways from cases of nonfatal and fatal asthma and controls

\begin{tabular}{|c|c|c|c|c|c|c|}
\hline & \multicolumn{2}{|c|}{ Control } & \multicolumn{2}{|c|}{ Nonfatal asthma } & \multicolumn{2}{|c|}{ Fatal asthma } \\
\hline & Cartilaginous & Membranous & Cartilaginous & Membranous & Cartilaginous & Membranous \\
\hline $\mathrm{n}$ & 39 & 59 & 43 & 90 & 41 & 77 \\
\hline $\mathrm{Pbm} \mathrm{mm}$ mean $\pm \mathrm{SD}$ & $15.9 \pm 6.4$ & $2.3 \pm 1.5$ & $16.1 \pm 6.7$ & $2.3 \pm 1.3$ & $15.5 \pm 5.7$ & $2.4 \pm 1.3$ \\
\hline Total mast cell count & $285 \pm 35$ & $47 \pm 9$ & $333 \pm 49$ & $61 \pm 16^{\#}$ & $229 \pm 27 *$ & $68 \pm 16^{\#}$ \\
\hline Mast cell density cells $\cdot \mathrm{mm}^{-2}$ & $27 \pm 9$ & $155 \pm 21$ & $24 \pm 2$ & $270 \pm 51^{\#}$ & $16 \pm 2 *$ & $219 \pm 26^{\#}$ \\
\hline Degranulated cells \% & $63 \pm 6$ & $42 \pm 3$ & $75 \pm 5$ & $66 \pm 4 *$ & $86 \pm 3^{\#}$ & $75 \pm 4^{\#, \oplus}$ \\
\hline
\end{tabular}

Data are presented as mean \pm SEM unless otherwise stated. Pbm: basement membrane perimeter. *: $\mathrm{p}<0.05$ compared with control and nonfatal asthma cases; ${ }^{\#}: \mathrm{p}<0.05$ compared with control cases; ${ }^{\uparrow}: \mathrm{p}<0.05$ compared with cartilaginous airways.

cases of fatal and nonfatal asthma compared with control cases (table 2).

\section{Mast-cell density in airway wall compartments}

Cartilaginous airways. Figure 3a shows mast-cell density in different airway wall compartments in cartilaginous airways. In control cases, the density of mast cells varied $>50$-fold across the airway wall, being highest on the smooth muscle $\left(74 \pm 17\right.$ cells $\left.\cdot \mathrm{mm}^{-2}\right)$, intermediate in the inner airway wall $\left(35 \pm 3\right.$ cells $\left.\cdot \mathrm{mm}^{-2}\right)$, submucosal glands $\left(39 \pm 9\right.$ cells $\left.\cdot \mathrm{mm}^{-2}\right)$ and outer airway wall $\left(7 \pm 1 \mathrm{cells} \cdot \mathrm{mm}^{-2}\right)$ and was lowest in the epithelium $\left(1.5 \pm 0.4\right.$ cells $\left.\cdot \mathrm{mm}^{-2}\right)$ and lumen $\left(0.2 \pm 0.1\right.$ cells $\left.\cdot \mathrm{mm}^{-2}\right)$. In submucosal mucous glands, all mast cells were seen within the supporting stromal tissue surrounding glands and no cells were noted within individual serous or mucinous acini. Similar patterns were observed in the nonfatal and fatal cases of asthma. Compared with control cases, however, the density was significantly lower $(\mathrm{p}<0.05)$ in the smooth muscle, the inner airway wall and the epithelium of nonfatal and fatal cases. The density of mast cells in the lumen was higher $(p<0.05)$ in the fatal cases compared with nonfatal cases of asthma, and both were higher than control cases $(p<0.05)$. The density of mast cells on submucosal glands was significantly higher $(\mathrm{p}<0.05)$ in nonfatal compared with fatal cases of asthma and controls. In the outer airway wall there were no significant differences between the case groups.
Membranous airways. Figure 3b shows mast-cell density in different airway wall compartments in membranous airways. In control cases, the highest density of mast cells was on the smooth muscle (201士 27 cells $\cdot \mathrm{mm}^{-2}$ ) and in the outer airway wall area $\left(163 \pm 17\right.$ cells $\left.\cdot \mathrm{mm}^{-2}\right)$. The density in the inner wall area $\left(78 \pm 12\right.$ cells $\left.\cdot \mathrm{mm}^{-2}\right)$, lumen $\left(1 \pm 0.5\right.$ cells $\left.\cdot \mathrm{mm}^{-2}\right)$ and epithelium $\left(0.8 \pm 0.6\right.$ cells $\left.\cdot \mathrm{mm}^{-2}\right)$ were significantly lower. In the nonfatal cases, the density of mast cells was significantly higher $(\mathrm{p}<0.05)$ on the smooth muscle and in both the inner and the outer airway wall areas compared with control cases. In the fatal cases, the density of mast cells was higher in the outer wall area, lumen and epithelium, compared with control cases. The overall density of mast cells in membranous airways was an order of magnitude higher than in the cartilaginous airways (table 2 and fig. $3 a$ and b).

Per cent of total mast cells in different airway wall compartments

Cartilaginous airways. Figure 4a shows the per cent of total mast cells in different airway wall compartments in cartilaginous airways. Within the airway wall, the distribution of mast cells into the different compartments was similar in the three case groups except the submucosal mucous glands where the per cent of total mast cells was higher in the asthma cases. The highest percentages of mast cells were seen in both the inner and outer airway wall reflecting the greater area 
a)

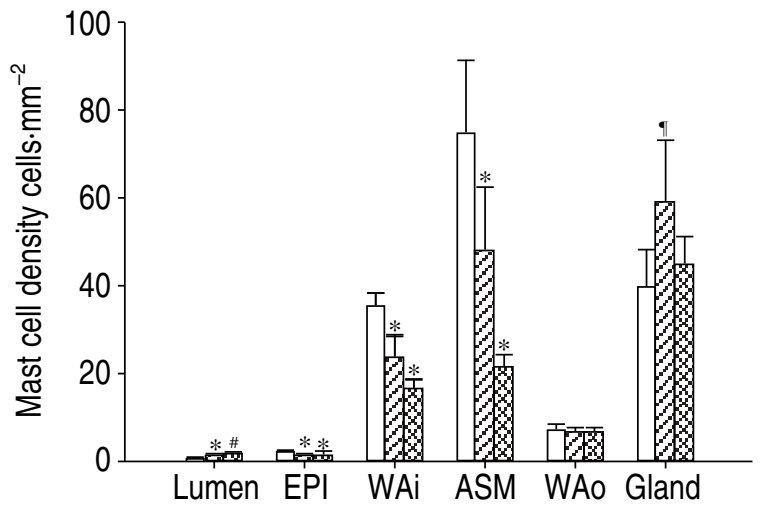

b)

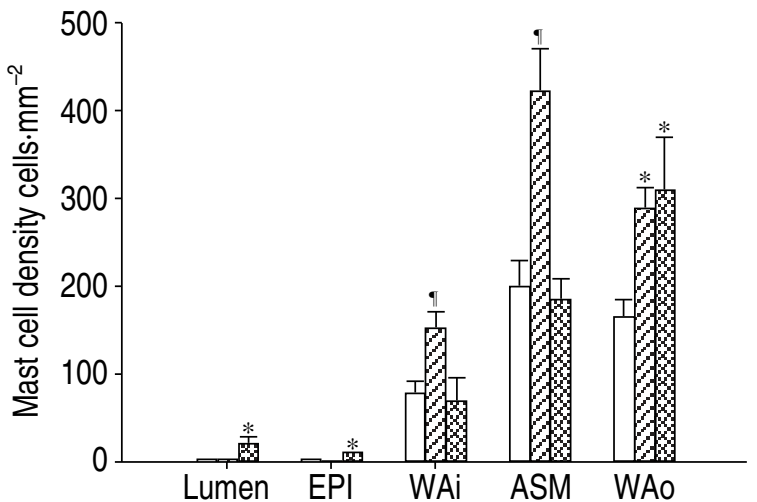

Fig. 3.-Mast-cell density in a) cartilaginous and b) membranous airways. EPI: epithelium; WAi: inner airway wall; ASM: airway smooth muscle; WAo: outer airway wall; Gland: submucosal mucous glands. $\square$ : control; $\mathbb{Z}$ : nonfatal asthma cases; $\mathbf{a}$ : fatal asthma cases. *: p $<0.05$ compared with control cases; ${ }^{*}$ p $<0.05$ compared with control and nonfatal cases; ${ }^{\uparrow}$ : $p<0.05$ compared with control and fatal cases.

of these compartments on transverse section. In the epithelium, the per cent of mast cells was higher $(\mathrm{p}<0.05)$ in the control cases compared with the fatal and nonfatal asthma cases, whereas in the airway lumen, the per cent of mast cells was higher $(\mathrm{p}<0.05)$ in fatal than nonfatal asthma cases and control cases.

Membranous airways. Figure $4 \mathrm{~b}$ shows the per cent of total mast cells in different airway wall compartments in membranous airways. The greatest percentage of mast cells was observed in the outer airway wall, the largest compartment in membranous airways. In the cases of fatal asthma, the per cent of mast cells was higher $(p<0.05)$ in the outer airway wall and airway lumen but was lower $(\mathrm{p}<0.05)$ in the inner airway wall and on the airway smooth muscle compared with control and nonfatal asthma cases. Fatal asthma and control cases had a higher per cent $(p<0.05)$ of total mast cells in the epithelium than the cases of nonfatal asthma.

\section{Degranulation}

The average percentage of degranulated mast cells was higher $(p<0.05)$ in cartilaginous airways than in membranous airways in all case groups. Compared with control cases, the percentage of degranulated mast cells was higher $(\mathrm{p}<0.05)$ in cases of nonfatal a)

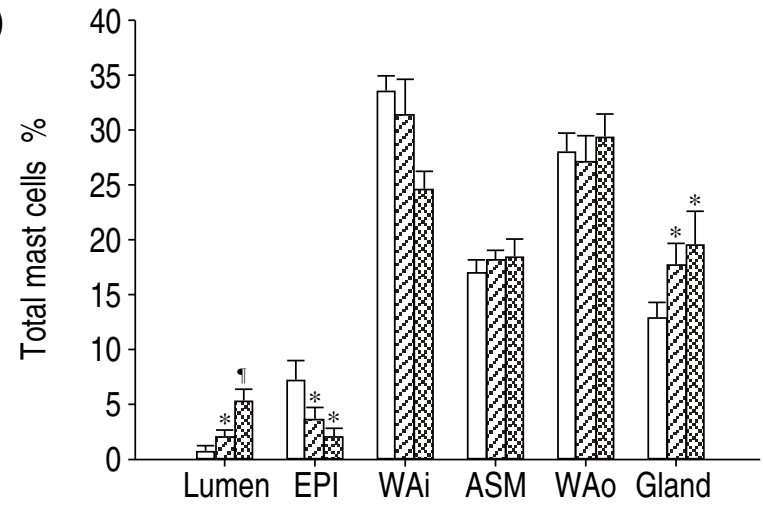

b)

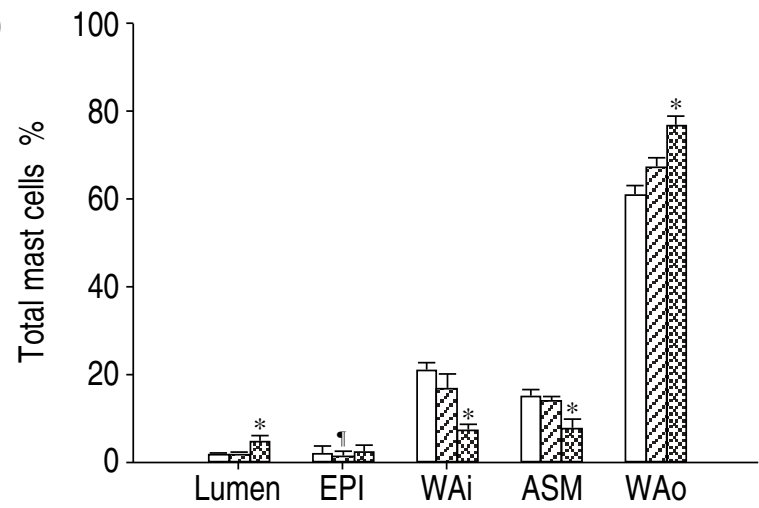

Fig. 4.- Per cent of total mast cells in a) cartilaginous and b) membranous airways. EPI: epithelium; WAi: inner airway wall; ASM: airway smooth muscle; WAo: outer airway wall; Gland: submucosal mucous glands. $\square$ : control; $\mathbb{Z}$ : nonfatal asthma cases; : fatal asthma cases. *: p $<0.05$ compared with control cases; \#. $\mathrm{p}<0.05$ compared with control and nonfatal cases.

asthma and higher again in cases of fatal asthma (table 2). The differences in degranulation between the control and asthma case groups were similar in the different airway wall compartments, in both cartilaginous (fig. 5a) and membranous (fig. 5b) airways for the three case groups. However, degranulation was significantly higher on the airway smooth muscle mast cells in cases of fatal asthma compared with both control and nonfatal asthma cases.

The coefficient of variation for intraobserver error was 3\% for airway dimensions, $11 \%$ for cell counts and $10 \%$ for the degranulation index.

\section{Discussion}

Insights can be gained from examining the distribution of mast cells across the airway wall. Firstly, the extent to which small samples from bronchial biopsies of large cartilaginous airways are representative of inflammatory processes deeper in the airway wall or in more distal sites in the bronchial tree can be assessed. The present study has shown that mast-cell density in the inner wall differs from that in the outer airway wall, smooth muscle and mucous glands. Moreover, the density in proximal airways was much lower than that in distal airways. Secondly, the relatively higher density of cells in smooth muscle 
a)

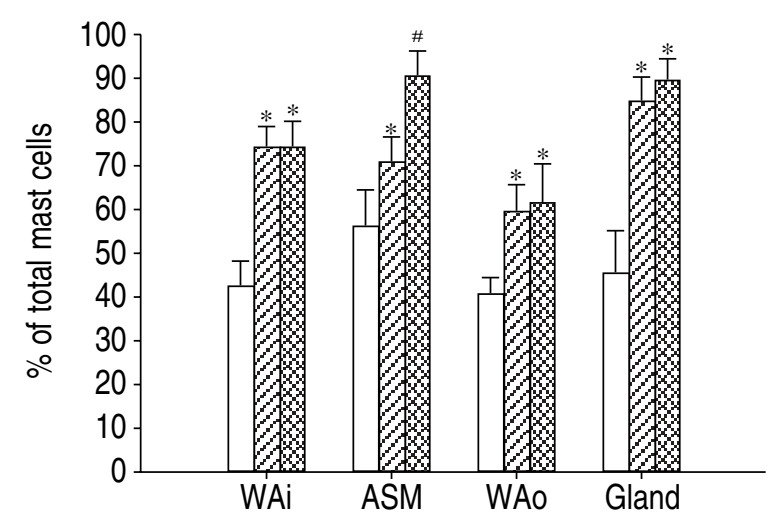

b)

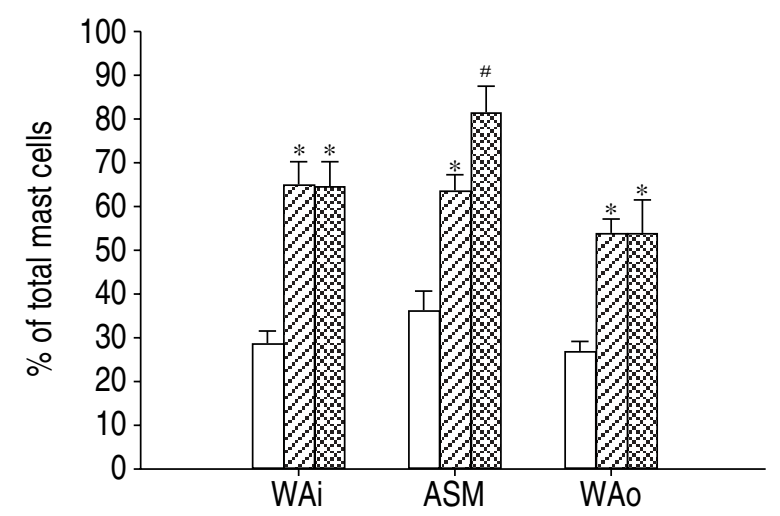

Fig. 5. - Per cent of degranulated mast cells in a) cartilaginous and b) membranous airways. WAi: inner airway wall; ASM: airway smooth muscle; WAo: outer airway wall; Gland: submucosal mucous glands. $\square$ : control; $\mathbb{Z}$ : nonfatal asthma cases; fatal asthma cases. *: $\mathrm{p}<0.05$ compared with control cases; ${ }^{\#}: \mathrm{p}<0.05$ compared with control and nonfatal cases.

and mucous glands suggests that they may be important in regulating the function of these tissues. Thirdly, the relation of mast-cell degranulation to asthma severity suggests an active role as effector cells in airway wall inflammation. Fourthly, the higher number of degranulated mast cells in cartilaginous compared with membranous bronchioles is consistent with an inhaled stimulus activating these cells.

Mast-cell numbers in this study were expressed both as total numbers per transverse section and as density (the number of cells $\cdot \mathrm{mm}^{-2}$ of area measured). This method of cell number estimation is a profile count of cells within a 3-dimensional (3D) structure and may be subject to bias if certain conditions are not met [12]. Firstly, sampling of tissues and fields of interest for measurements need to be performed in a systematic random fashion. Secondly, all cells of interest must have an equal probability of being counted. This depends largely on cell size and orientation. Thirdly, the reference area for measurements (i.e. a 2-dimensional (2D) profile area) should be related to the $3 \mathrm{D}$ volume that the profile represents if absolute cell number in the airway volume are to be determined. In the present study, the sampling processes, from lung collection to individual airway blocks and sections, were systematic and random. Cells were identified using immunohistochemical staining but only counted if nucleated. The size of the mast-cell nucleus does not vary significantly [13] and is small compared with the reference section in which it was measured in this study. Because the authors were unable to define an initial reference volume for the whole lung, and did not use a "lookup" section, the 2D profile counts in this study could not be converted into a 3D volume estimate of absolute cell numbers. However, since nucleus size and orientation were not likely to have systematically changed between groups, the authors felt that these limitations would not affect comparisons between groups. Since measurement variability is predominantly due to subject and tissue-block variability [14], a large number of randomly-selected airways from different sites in the lung were examined and the mean data from each case was used to compare cell numbers between groups. Therefore, comparisons of relative cell densities between the groups in this study are valid and make the data directly comparable with the many other published studies that have reported cell numbers in this way.

Previous studies of mast-cell numbers in the airways have shown that compared with control cases, those with asthma have higher [5, 6], decreased [8], or similar $[9,10,15,16]$ numbers of mast cells. The variation between studies may be due to variations in asthma severity, use of different methodologies, effects of treatment and variations in the degree of degranulation [17-20]. To the authors' knowledge, no previous studies have systematically quantified mast-cell degranulation. The higher concentrations of mast-cell derived mediators, such as histamine, prostaglandin $\mathrm{D}_{2}\left(\mathrm{PGD}_{2}\right)$, leukotriene $\mathrm{C} 4$ (LTC4) and tryptase seen in bronchoalveolar lavage (BAL) fluid in the early- and late-phase asthmatic reaction following local-allergen challenge [21], suggest mastcell degranulation. The amount of degranulation was greatest in fatal asthma cases, suggesting increased mast-cell activation in these cases. In addition, increased degranulation may have caused underestimation of the number of mast cells in these cases (i.e. by not counting cells where there were no granules left).

The amount of mast-cell degranulation was found to be greatest in the submucosal mucous glands and on the airway smooth muscle layer in fatal asthma cases. Pesci et al. [22] showed an increase in the number of degranulated mast cells in the mucous glands of patients with chronic bronchitis, a disease characterized by excessive mucus production, and BRADDING [11] observed that interleukin-6 positive mast cells are concentrated in close proximity to submucosal mucous glands [7]. It is well documented that mast-cell derived proteases are capable of acting as potent secretagogues and that histamine, which is stored in and secreted from activated mast cells, stimulates smooth muscle shortening and vasodilatation [23]. The authors have shown previously that increased secretion of mucus into the airway lumen combined with moderate amounts of smooth-muscle shortening in vivo, may give rise to exaggerated airway narrowing [24], which may contribute to sudden fatal 
asthma attacks [25]. These findings suggest the mast cell to be an important effector cell during an acute attack of asthma.

The finding that the density of mast cells was highest on the smooth-muscle layer compared with other airway wall compartments is similar to the findings of Aмmiт et al. [3] and Berger et al. [4]. The present study is the first quantitative evidence that mast cells are the predominant cell within the airway smooth-muscle layer in both nonasthmatics and asthmatics, and that those present on the smooth muscle layer in cases of fatal asthma are mostly degranulated. CoNNELL [8] noted accumulation of mast cells near the smooth-muscle layer in cartilaginous bronchi from cases of fatal asthma. During an acute episode of asthma, activation of mast cells might cause abnormal release of chemical mediators, resulting in excessive stimulation of smooth muscle and mucous glands. This hypothesis is supported by the findings of elevated amounts of mast-cell derived mediators in BAL fluid from cases of asthma following allergen challenge [26] and lower numbers of mast cells in biopsies obtained from patients during an episode of asthma than during symptom-free periods [27].

One potential mechanism that may cause mast cell numbers in the airway wall to be reduced during asthma exacerbations is the movement of cells from the airway wall into the airway lumen. This is supported by the observation in this study of a higher percentage of mast cells in the lumen of fatal asthma cases compared with nonfatal asthma and nonasthmatic control cases. In addition, higher numbers of mast cells are observed in the sputum of atopic asthmatics after allergen-inhalation challenge [20]. Another potential mechanism for reduced mast-cell numbers is increased apoptosis of cells. While the degree of mast-cell apoptosis was not assessed in this study and therefore cannot be excluded as a mechanism for reducing cell numbers, persistent inflammatory conditions are usually characterized by delayed or impaired apoptosis.

The degree of mast-cell degranulation in the present study was higher in the cartilaginous (proximal) airways compared with the membranous (distal) airways. It is tempting to speculate that a major reason for this is that the predominant stimulus for mast-cell degranulation occurs close to the mucosal surface of the airway and, to a greater extent, in the proximal bronchial tree, due to an inhaled stimulus. In the present study, the level of mast-cell degranulation in the mucous glands in all cases of asthma was significantly higher than that observed in the outer airway wall, suggesting selective stimulation of mast cells. A mechanism that may explain this, is the fact that neuropeptides are capable of inducing mastcell degranulation [28] and there is an abundance of cholinergic nerves present in the airway epithelium that have local axonal pathways to submucosal mucous glands [29]. Thus, stimulation of these nerves at the mucosal surface and subsequent release of neuropeptides may lead to increased mast-cell degranulation of mucous glands.

The density of mast cells was lower in the cartilaginous airways than the membranous airways in asthma cases compared with control cases. Similarly, the study of CONNELL [8] also reported decreased numbers of mast cells in the airway wall in cartilaginous airways from fatal asthma cases compared with control cases. Studies examining the numbers of mast cells in bronchial biopsies from the proximal bronchial tree in cases of mild asthma show variation, in that some studies show an increase in mast cells within the airway wall $[5,30]$, some in the epithelium only [6], and others showed no difference at all $[9,10,15,16]$. This variation may be due to degranulation, apoptosis or the effects of anti-inflammatory treatment. Nonetheless, the present study clearly demonstrates that bronchial biopsy obtained from the proximal bronchial tree may not always represent the pattern of inflammation across the airway wall or along the entire length of the bronchial tree.

In conclusion, in addition to their clearly defined role in immunoglobulin-E-dependent responses to antigenic stimulation in atopic disorders such as asthma, it is possible that mast cells may markedly amplify many features of the host response to nonspecific acute inflammatory stimuli, such as that seen in asthmatics in response to exercise, cold air and hypertonic saline inhalation. The separate activity of mast cells in the airways should be considered in both short-term and long-term treatment strategies.

\section{References}

1. Djukanovic WR, Roche WR, Wilson JW, et al. Mucosal inflammation in asthma. Am Rev Respir Dis 1990; 142: $434-457$.

2. Carroll NG, Elliot J, Morton AR, James AL. The structure of large and small airways in nonfatal and fatal asthma. Am Rev Respir Dis 1993; 147: 405-410.

3. Ammit AJ, Bekir SS, Johnson PRA, Hughes JM, Armour CL, Black JL. Mast cell numbers are increased in the smooth muscle of human sensitized isolated bronchi. Am J Respir Crit Care Med 1997; 155: 1123-1129.

4. Berger P, Walls AF, Marthan R, Tunon-de-Lara JM. Immunoglobulin E-induced passive sensitization of human airways: An immunohistochemical study. Am J Respir Crit Care Med 1998; 157: 610-616.

5. Pesci A, Foresi A, Bertorelli AC, Oliveri D. Histochemical characteristics and degranulation of mast cells in epithelium and lamina propria of bronchial biopsies from asthmatic and normal subjects. Am Rev Respir Dis 1993; 147: 684-689.

6. Laitinen LA, Laitinen A, Haahtela T. Airway mucosal inflammation even in patients with newly diagnosed asthma. Am Rev Respir Dis 1993; 147: 697-704.

7. Wardlaw AJ, Dunnett S, Gleich GJ, Collins JV, Kay AB. Eosinophils and mast cells in bronchoalveolar lavage in mild asthma: relationship to bronchial hyperreactivity. Am Rev Respir Dis 1988; 137: 62-69.

8. Connell JT. Asthmatic deaths: role of the mast cell. JAMA 1971; 215: 769-772.

9. Bradley BL, Azzawi M, Jacobson M, et al. Eosinophils, T-lymphocytes, mast cells, neutrophils, and macrophages in bronchial biopsy specimens from atopic subjects with asthma: comparison with biopsy 
specimens from atopic subjects without asthma and normal control subjects and relationship to bronchial hyperresponsiveness. J Allergy Clin Immunol 1991; 88: 661-674.

10. Djukanovic R, Wilson JW, Britten KM, et al. Quantitation of mast cells and eosinophils in the bronchial mucosa of symptomatic atopic asthmatics and healthy control subjects using immunohistochemistry. Am Rev Respir Dis 1990; 142: 863-871.

11. Bradding P. Interleukins (IL)-4, $-5,-6$ and $\mathrm{TNFa}$ in normal and asthmatic airways: evidence for the human mast cell as an important source of these cytokines. Am J Respir Cell Mol Biol 1994; 10: 471480.

12. Weibel ER, Gomez DM. A principle for counting tissue structures on random sections. J Appl Physiol 1962; 17: 343-348.

13. Jeffery PK, Heard BE, Kay AB. Do mast cells degranulate in the bronchial mucosa of mildly symptomatic atopic asthmatic subjects? Am Rev Respir Dis 1992; 145: A23.

14. Gundersen H, Osterby R. Optimizing sampling efficiency of stereological studies in biology. J Microscopy 1981; 121: 65-73.

15. Beasley R, Roche W, Roberts JA, Holgate ST. Cellular events in the bronchi in mild asthma and after bronchial provocation. Am Rev Respir Dis 1989; 139: 806-817.

16. Vignola AM, Chanez P, Campbell AM, et al. Airway inflammation in mild intermittent and in persistent asthma. Am J Respir Crit Care Med 1998; 157: 403409.

17. Trigg CJ, Manolitsas ND, Wang J, et al. Placebocontrolled immunopathologic study of four months of inhaled corticosteroids in asthma. Am J Respir Crit Care Med 1994; 150: 17-22.

18. Djukanovic R, Wilson JW, Britten K, et al. Effect of an inhaled corticosteroid on airway inflammation and symptoms in asthma. Am Rev Respir Dis 1992; 145: 669-674.

19. Bentley AM, Hamid Q, Robinson DS, et al. Prednisolone treatment in asthma: Reduction in the numbers of eosinophils, T cells, tryptase-only positive mast cells, and modulation of IL-4, IL-5, and interferongamma cytokine gene expression within the bronchial mucosa. Am J Respir Crit Care Med 1996; 153: 551556.

20. Gauvreau GM, Lee JM, Watson RM, Irani AM, Schwartz LB, O'Byrne PM. Increased numbers of both airway basophils and mast cells in sputum after allergen inhalation challenge of atopic asthmatics. $\mathrm{Am}$ J Respir Crit Care Med 2000; 161: 1473-1478.

21. Metzger WJ, Zavala D, Richerson HB, et al. Local allergen challenge and bronchoalveolar lavage of allergic asthmatic lungs. Description of the model and local airway inflammation. Am Rev Respir Dis 1987; 135: 433-440.

22. Pesci A, Rossi GA, Bertorelli G, Aufiero A, Zanon P, Olivieri D. Mast cells in the airway lumen and bronchial mucosa of patients with chronic bronchitis. Am J Respir Crit Care Med 1994; 149: 1311-1316.

23. Nadel JA. Biologic effects of mast cell enzymes. Am Rev Respir Dis 1992; 145: s37-s41.

24. James AL, Carroll NG. The theoretical effects of mucous gland discharge on airway resistance in asthma. Chest 1995; 107: 110s.

25. Carroll NG, Carello S, Cooke C, James A. Airway structure and inflammatory cells in fatal attacks of asthma. Eur Respir J 1996; 9: 709-715.

26. Liu MC, Bleecker ER, Lichtenstein LW, et al. Evidence for elevated levels of histamine, prostaglan$\operatorname{din} \mathrm{D}_{2}$, and other bronchoconstricting prostaglandins in the airways of subjects with mild asthma. Am Rev Respir Dis 1990; 142: 126-132.

27. Bhat KN, Arroyave CM, Marney SR, Stevenson DD, Tan EM. Plasma histamine changes during provoked bronchospasm in asthmatic patients. J Allergy Clin Immunol 1976; 58: 647-656.

28. Forsythe P, McGarvey LP, Heaney LG, MacMahon J, Ennis M. Sensory neuropeptides induce histamine release from bronchoalveolar lavage cells in both nonasthmatic coughers and cough variant asthmatics. Clin Exp Allergy 2000; 30: 225-232.

29. Jeffery PK. Structural, immunological and neural elements of the normal human airway wall. In: Busse WW, Holgate ST, eds. Asthma and Rhinitis 2nd Edn. Oxford, Blackwell Scientific, 2000; pp. 164-190.

30. Lozewicz S, Gomez E, Ferguson H, Davies RJ. Inflammatory cells in the airways in asthma. BMJ 1988; 297: 1515-1516. 